\title{
PROFIL KLT BEBERAPA JENIS KOPI DI SUMATERA DAN POTENSI ANTIOKSIDANNYA
}

\author{
Profile of TLC in Several Types of Coffee in Sumatra and \\ its Antioxidant Potential \\ Irwan Sudarmanto \\ Institut Teknologi Sumatera (ITERA) \\ e-mail : sudarmantoirwan2016@gmail.com \\ 085928010528
}

\begin{abstract}
This study shows that the three coffee samples, namely Lampung coffee, Medan coffee and Aceh coffee have the main phytochemical content that is identical with alkaloid compounds, tannins, phenol compounds, tannins and flavonoids. The TLC test is used to be able to confirm the origin of the type of coffee against the polar fraction (ethanol) and nonpolar fraction (chloroform). In this study, the results of the chromatogram were identical so that in this study the use of the TLC method could not be used to determine the biomarkers contained in the coffee samples. The antioxidant potential for Lampung Coffee, Medan Coffee and Aceh Coffee is 15.60 ppm, 13.24 ppm and 13.40 ppm.
\end{abstract}

Keywords: antioxidant, coffee, TLC, phytochemical

\begin{abstract}
Abstrak
Penelitian ini menunjukkan bahwa ketiga sampel kopi yaitu kopi Lampung, kopi Medan dan Kopi Aceh memiliki kandungan fitokimia utama yang identik yaitu senyawa alkaloid, tannin, senyawa fenol, tannin dan flavonoid. Uji KLT yang digunakan untuk dapat mengkonfirmasi asal jenis kopi tersebut terhadap fraksi polar (etanol) dan fraksi nonpolar (kloroform). Pada penelitian ini menunjukan hasil kromatogram yang identik sehingga pada penelitian ini penggunaan metode KLT belum bisa digunakan untuk menentukan biomarker yang terkandung dalam sampel kopi tersebut. Potensi antioksidan untuk Kopi Lampung, Kopi Medan dan Kopi Aceh adalah 15,60 ppm, 13,24 ppm dan 13,40 ppm.
\end{abstract}

Kata Kunci: antioksidan, kopi, KLT, fitokimia 


\section{PENDAHULUAN}

Kopi merupakan salah satu minuman favorit dan mengandung banyak manfaat. Tiap daerah memiliki kopi yang khas baik dalam rasa maupun aromanya. Di pulau Sumatera beberapa daerah menjadi produsen kopi yang memiliki karakteristik tertentu seperti Lampung, Medan, Palembang dan Aceh. Perbedaan karakter tersebut tergantung pada habitat dimana tanaman kopi tersebut tumbuh. Perlu ada metode ilmiah yang dapat membuktikan perbedaan jenis kopi tersebut. Penelitian ini bertujuan untuk mengetahui apakah metode KLT dapat digunakan untuk mengkonfirmasi darimana kopi tersebut berasal.

KLT merupakan metode yang umum dipilih dalam analisis awal preparat herbal sebelum adanya kromatografi instrumental seperti kromatografi gas dan kromatografi cair kinerja tinggi, bahkan hingga saat ini. Beberapa farmakope masih menggunakan KLT untuk memperoleh profil karakteristik dari tanaman. Validasi metode KLTDensitometri yang dapat menguji secara simultan marker strikhnin dan brusin dan menerapkannya untuk identifikasi dan kuantitasi produk yang dalam formulasinya mengandung biji Strychnos nux-vomica [1]. Berdasarkan penelitian tersebut diperoleh metode yang sederhana, sensitif dan spesifik. Penetapan secara simultan stemokurtisin, stemokurtisinol dan stemofolin dalam akar Stemona curtisii (Stemonaceae), ekstrak dan produknya serta produk lain yang mengandung marker. Dalam hal ini penelitina berikut dimaksudkan untuk dapat mengidentifikasi marker dari ketiga jenis kopi berikut sehingga dapat digunakan sebagai identifikasi awal dari jenis kopi bersangkutan.

Salah satu manfaat kopi yang telah diketahui masyarakat adalah realitas bahwa kopi memiliki khasiat dalam kesehatan seperti sebagai stimulant dan memiliki kemampuan sebagai agen antioksidan [2]. Antioksidan merupakan suatu senyawa yang dapat menginaktifkan radikal bebas yang dihasilkan oleh berbagai proses normal tubuh, radiasi matahari, asap rokok, asap kendaraan bermotor dan faktor-faktor lain. Adapun radikal bebas adalah suatu bahan kimia baik berupa atom maupun molekul yang memiliki elektron tidak berpasangan pada lapisan luarnya yang menjadikan spesies ini sangat reaktif, karena mempunyai energi yang sangat tinggi dan kecenderungan untuk berikatan dengan elektron dari substrat lain, zat ini akan merusak jaringan normal terutama jika jumlahnya terlalu banyak. Radikal bebas dapat mengganggu produksi DNA, lapisan lipid pada dinding sel, mempengaruhi pembuluh darah, dan produksi prostaglandin

\section{METODE PENELITIAN}

\section{Alat}

Alat-alat yang digunakan pada penelitian ini adalah Labu ukur, erlenmeyer, pipet, spektro UV, kolom kromatografi, plat KLT $\mathrm{GF}_{254}$, lampu UV, seperangkat alat gelas, evaporator

\section{Bahan}

Aquades, metanol, kloroform, heksana, etil asetat, serbuk $\mathrm{Mg}, \mathrm{HCl}$ pekat, serbuk DPPH, butanol, etanol $70 \%$, silika gel, $\mathrm{Na}$ asetat anhidrat, $\mathrm{FeCl}_{3}$,diklorometan. Kopi Lampung (daerah Lampung Barat), Kopi Medan (daerah Deli) dan Kopi Aceh (daerah Gayo)

\section{Prosedur}

\section{Ekstraksi Bahan}

$100 \mathrm{~g}$ buah kopi yang telah masak (ditandai dengan warna buah yang berwarna merah) dikupas dari kulitnya lalu dikeringkan dan diangin anginkan selama 1 minggu kemudian dijadikan serbuk dan diayak dengan ukuran 65 mesh 
selanjutnya direndam dalam heksana $1000 \mathrm{~mL}$ selama 3 hari disaring dan dimaserasi $1000 \mathrm{~mL}$ etanol p.a selama 3 hari. Filtrat diuapkan dengan rotary evaporator hingga didapat $15 \mathrm{~g}$ ekstrak pekat yang selanjutnya di partisi dengan corong pisah dengan pelarut heksana, kloroform, dan etanol p.a

\section{Analisa Data}

Ketiga sampel kopi diuji kandungan kimianya dengan menggunakan metode sederhana. Identifikasi meliputi kandungan alkaloid, flavonoid, senyawa fenolik, tanin dan saponin [3]

\section{Uji alkaloid}

Sebanyak 4 g sampel ditimbang dan diserbuk selanjutnya tambahkan $1 \mathrm{ml}$ kloroform dan sedikit pasir.Tambahkan 10 $\mathrm{ml}$ 0,05 $\mathrm{N}$ larutan ammonia dalam kloroform. Larutan dikocok selama 1 menit dan disaring lalu masukkan dalam tabung reaksi. Tambahkan $2 \mathrm{ml} \quad \mathrm{H}_{2} \mathrm{SO}_{4}$ dan dikocok, biarkan beberapa saat hingga terbentuk dua lapisan. Lapisan paling atas dipisahkan dan direaksikan dengan pereaksi Mayer, Wagner dan Dragendorf. Sampel positif mengandung alkaloid jika terdapat endapatan putih dengan pereaksi Mayer, endapan kuning kecoklatan dengan pereaksi Wagner dan endapan jingga dengan pereaksi Dragendorf.

\section{Uji flavonoid}

Dilakukan dengan menyari sebanyak 0,5 $g$ serbuk sampel menggunakan $5 \mathrm{ml}$ etanol panas dalam tabung reaksi. Selanjutnya disaring dan filtrate direaksikan menggunakan pereaksi Shinoda, yaitu dengan menmbahkan sebanyak 5 tetes $\mathrm{HCl}$ pekat biarkan beberapa saat dan tambahkan serbuk $\mathrm{Mg}$ sebanyak 1mg. Sampel positif mengandung flavonoid jika terbentuk warna merah tua.

\section{Uji tannin}

Sejumlah $100 \mathrm{mg}$ serbuk ditambah 100 $\mathrm{mL}$ air panas lalu didihkan selama 5 menit dalam Erlenmeyer. Saring dengan menggunakan kertas saring, filtrate yang diperoleh ditambahkan dengan larutan FeCl3 1\%. Hasil positif ditunjukkan dengan terbentuknya warna hijau violet (tanin terkondensasi) atau biru kehitaman (tanin terhidrolisis) [4].

\section{Uji senyawa fenolik}

Sejumlah $100 \mathrm{mg}$ sampel dimasukkan dalam tabung reaksi lalu tambahkan etanol $80 \%$ disonikasi selama 20 menit selanjutnya saring dengan kapas. $1 \mathrm{ml}$ filtrat diambil dan ditetesi dengan larutan Folin Ciocalteu, diamkan selama 5 menit di tempat gelap. Sampel positif jika terbentuk warna biru [5].

\section{Uji saponin}

Sejumlah $100 \mathrm{mg}$ serbuk dimasukkan dalam tabung reaksi selanjutnya tambahkan $10 \mathrm{~mL}$ lalu dinginkan dan kocok kuat- kuat selama 10 detik. Jika terbentuk buih yang tidaka hilang selama 10 menit maka sampel mengandung saponin

\section{Uj Aktivitas Antioksidan}

Uji kuantitatif aktivitas antioksidan dinyatakan sebagai $\mathrm{IC}_{50}$ yang dilakukan dengan tahapan berikut : Buat larutan stok DPPH pada konsentrasi yang memberi serapan pada angka sekitar 1,0 yaitu pada konsentrasi 50-100 $\mu \mathrm{M}$ [6]. Lalu buat juga larutan senyawa uji sehingga diperoleh konsentrasi tertentu lalu tambahkan DPPH $50 \mu \mathrm{g} / \mathrm{mL}$ dengan perbandingan volume sama (1:1) pada setiap seri konsentrasi dan diinkubasi selama 30 menit pada suhu $37^{\circ} \mathrm{C}$. Absorbansi diukur pada 515-517 nm. Kontrol positif menggunakan larutan vitamin $\mathrm{C}$ dengan kadar 15, 29, 30 dan 40 ppm dan diperlakukan seperti pada larutan uji. Nilai absorbansi yang diperoleh kemudian dikonversi menjadi 
nilai $\mathrm{IC}_{50}$ dengan cara membuat persamaan garis regresi linear, $y=b x+a$ dimana $\mathrm{y}=$ daya hambat terhadap DPPH dan $\mathrm{x}=$ kadar senyawa uji. Daya hambat dinyatakan sebagai \% daya hambat terhadap DPPH dan dihitung dengan persamaan berikut

$\%$ daya hambat $=\left(1-\frac{\text { absorbansi akhir }}{\text { absorbansi awal }}\right) \times 100 \%$

Nilai $\quad \mathrm{IC}_{50}$ merupakan hasil ekstrapolasi dari persamaan $y=b x+a$ di atas, nilai ini menggambarkan kadar suatu senyawa yang dapat menonaktifkan separuh dari kekuatan DPPH.

\section{HASIL DAN PEMBAHASAN}

\section{Kandungan fitokimia kopi}

Identifikasi kandungan fitokimia terhadap ketiga jenis sampel menunjukkan bahwa ketiganya memiliki kandungan fitokimia yang identik seperti terlihat pada Tabel 1. Hal ini dapat menggambarkan bahwa habitat tumbuh tanaman tidak mempengaruhi kandungan utama tanaman kopi.

Tabel 1. Kandungan fitokimia kopi

\begin{tabular}{l|c|c|c}
\hline Senyawa & $\begin{array}{l}\text { Kopi } \\
\text { Lampung }\end{array}$ & $\begin{array}{l}\text { Kopi } \\
\text { Medan }\end{array}$ & $\begin{array}{l}\text { Kopi } \\
\text { Aceh }\end{array}$ \\
\hline Alkaloid & + & + & + \\
\hline Saponin & + & + & + \\
\hline Flavonoid & + & + & + \\
\hline $\begin{array}{l}\text { Senyawa } \\
\text { fenolik }\end{array}$ & + & + & + \\
\hline Tanin & + & + & + \\
\hline
\end{tabular}

\section{Uji KLT}

Hasil fraksinasi di bagi dalam dua fraksi berdasarkan sifat kelarutannya yaitu fraksi polar dan fraksi non-polar. Selanjutnya pengujian KLT dilakukan terhadap fraksi polar (etanol) dan fraksi non polar (kloroform). Fraksi polar menunjukkan bahwa tidak terjadi perbedaan yang signifikan pada kromatogram yang diperoleh seperti terlihat pada Gambar 1. Fase gerak yang digunakan adalah heksan: diklorometan: etanol (5:3:2). Hal ini dimungkinkan karena hasil pengujian kandungan fitokimia utama dari ketiga jenis kopi tersebut tidak berbeda seperti pada Tabel 1. Perbedaan rasa dan aroma yang terjadi dimungkinkan bukan karena perbedaan kandungan zat aktif dalam kopi namun diduga karena rasio atau perbedaan perbandingan zat aktif dalam kopi dan cara pengolahan yang perlu dibuktikan dengan penelitian lebih lanjut.

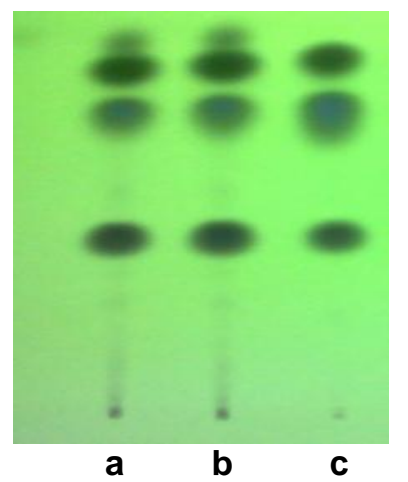

Gambar 1. Kromatogram KL GF 254 fraksi polar (etanol) sampel diamati dengan sinar UV 254 Fase gerak heksan: diklorometan ; etilasetat (5:3:2)
(a) Kopi Aceh (b)Kopi Medan

(c)Kopi Lampung

Adapun pengujian KLT terhadap fraksi non-polar (kloroform) menunjukkan hasil yang sama seperti kromatogram pada fraksi polar dimana tidak terdapat perbedaan yang signifikan yang dapat dijadikan biomarker atau senyawa pembeda dari ketiga jenis sampel tersebut. 


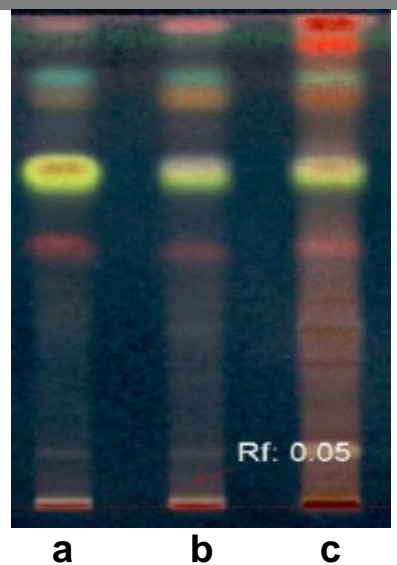

Gambar 2. Kromatogram KLT GF 254 fraksi non-polar (kloroform) sampel diamati dibawah sinar UV 366. Fase gerak heksan: etil asetat:etanol (10:4:2)

(a)Kopi Aceh (b)Kopi Medan

(c) Kopi Lampung

\section{Potensi Antioksidan}

Pengukuran potensi antioksidan terhadap ketiga sampel menunjukkan bahwa nilai $\mathrm{IC}_{50}$ yang terukur juga tidak berbeda jauh. Secara umum kopi memang dikenal sebagai minuman yang memiliki aktivitas antioksidan. Kontribusi antioksidan kopi terutama berasal dari kandungan flavonoid, tanin dan senyawa fenolik yang terdapat dalam kopi (lihat Tabel 1). Makin kecil nilai $\mathrm{IC}_{50}$ suatu sampel maka potensi antioksidannya semakin besar. Nilai $\mathrm{IC}_{50}$ vitamin $\mathrm{C}$ yang digunakan sebagai kontrol positif adalah seperti terlihat pada Tabel 2.

Tabel 2. Hasil pengukuran absorbansi, prosentase daya hambat dan $\mathrm{IC}_{50}$

\begin{tabular}{l|l|l}
\hline $\begin{array}{l}\text { Konsentrasi } \\
\text { (ppm) }\end{array}$ & absorbansi & $\begin{array}{l}\% \text { daya } \\
\text { hambat }\end{array}$ \\
\hline 15 & 0,350 & 58 \\
\hline 25 & 0,267 & 66 \\
\hline 30 & 0,259 & 70 \\
\hline 40 & 0,020 & 98 \\
\hline 50 & 0,012 & 99 \\
\hline
\end{tabular}

Absorbansi larutan DPPH 50 ppm $=0,824$

$Y=1,345 x+34,75$

$r^{2}=0,914$

$\mathrm{IC}_{50}=11,34 \mathrm{ppm}$
Selanjutnya nilai $\mathrm{IC}_{50}$ sampel ditentukan dengan mengkonversi nilai absorbansi yang diperoleh kedalam persamaan diatas sehingga diperoleh hasil seperti pada Tabel 3

Tabel 3. Nilai $\mathrm{IC}_{50}$ sampel kopi

\begin{tabular}{l|l|l|l}
\hline \multirow{2}{*}{$\begin{array}{l}\text { Nilai } \\
\text { IC } \\
\text { (pom) } \\
\text { (ppm) }\end{array}$} & \multicolumn{3}{|c}{ Jenis Kopi } \\
\cline { 2 - 4 } & Lampung & Medan & Aceh \\
\hline
\end{tabular}

\section{KESIMPULAN DAN SARAN}

\section{KESIMPULAN}

1. Metode KLT belum bisa digunakan sebagai instrument/metode yang dapat digunakan untuk mengkonfirmasi asal kopi

2. Ketiga jenis kopi memiliki kemampuan sebagai agen antioksidan yang sangat baik

3. Kemampuan antioksidan terutama hasil kontribusi senyawa fenolik dan flavonoid dalam kopi

\section{UCAPAN TERIMAKASIH}

Penulis mengucapkan terima kasih kepada Laboratorium Kimia Dasar Institut Teknologi Sumatera atas waktu dan tempatnya. Penulis juga mengucapkan banyak terima kasih kepada ITERA yang telah menyediakan dana untuk terlaksananya penelitian ini. Penelitian ini terselenggara atas skema bantuan Hibah Mandiri ITERA 2017.

\section{DAFTAR PUSTAKA}

[1] Dhalwal, K, Shinde, V. M., Namdeo, A. G., Mahadik, K. R. and Kadam, S. S. 2007. Development and Validation of a TLC-Densitometric Method for the Simultaneous Quantitation of Strychnine and Brucine from Strychnos spp. and its Formulations. Journal of Chromatographic Science. Vol. 45. 
[2] Ramalakshmi, K., I.R Kubra and L.J.M Rao. 2008. Antioxidant potential of Low-Grade Coffee Beans. Food Research International. 41:96-103

[3] Anonim. 1989. Materia Medika Indonesia jilid 3. Departemen Kesehatan Republik Indonesia. Jakarta

[4] EvansW.B., Trease .2002. Caffein in Pharmacognosy ED. 15 . W.B Sounders. New York.

[5] Harborne, J..B., 1987. Metode fitokimia: Penuntun cara modern menganalisis tumbuhan, Edisi 2 .Terjemahan Dr Kosasih Padmawinata dan Dr. Iwang Soediro . Penyunting Dr Sofia Mansoor. ITB PRESS. Bandung

[6] Molyneux, P. 2004. The Use of the Stable Free Radical Diphenyl picrylhidrazyl (DPPH) for Estimating Antioxidant Activity. Songklanakarin Journal of science and technology 26(2): $211-219$ 